\title{
SISTEM ADMINISTRASI PELAYANAN PUBLIK PERMOHONAN HAK ATAS TANAH DI KANTOR PERTANAHAN
}

\author{
ELIANA \\ Dosen Fakultas Hukum Universitas pamulang \\ E-mail: elianalia33@yahoo.com
}

\begin{abstract}
ABSTRAK
Penelitian ini mengenai bagaimana sistem administrasi pelayanan publik yang efektif dan efesien seharusnya dilakukan Kantor Pertanahan bagaimana konsep efesien efektifitas sistem administrasi pelayanan publik terhadap permohonan hak atas tanah di Kantor Pertanahan Peraturan Kepala Badan Pertanahan Nasional Republik Indonesia tanggal 22 April 2013 Nomor 6 tahun 2013 Tentang Pelayanan Informasi Publik di Lingkungan Badan Pertanahan Nasional Republik Indonesia. BPN sebagaimana Standar Prosedur Operasional Pengaturan Pelayanan (SPOPP) dan Undang-Undang Nomor 25 Tahun 2009 tentang Pelayanan Publik, fungsi yang dilaksanakan belum optimal, keberpihakan pelayanan terutama dibidang pertanahan, proses penyelesaian berbelit-belit dan mahal, Kesadaran pegawai Kantor pertanahan tentang Sapta Tertib Pertanahan masih kurang, sosialisasi prosedur pelayanan dan jenis-jenis pelayanan kurang di mengerti masyarakat, Apakah Kantor Pertanahan melaksanakan pelayanan Hak Atas Tanah yang efektif dan fesien. Penelitian ini menggunakan Metode dengan pendekatan socio-legal research yang bersumber dari pengumpulan data yang diperoleh dari data primer data sekunder, kemudian dianalisi dengan metode analisis kualitatif. Hasil penelitian memberikan jawaban bahwa pelaksanaan sistem adminitrasi pelayanan publik terhadap permohonan hak atas tanah di kantor pertanahan masih banyak yang belum diketahui masyarakat, bagaimana kemudahan dan pelayanan yang telah tersedia, sumber daya manusia pada setiap pegawai dengan persoalan persoalan terkait permohonan hak atas tanah belum semuanya mumpuni sementara Kantor Pertanahan telah melakukan inovasi pelayanan dengan tehnologi dan inovasi sehingga proses pendaftaran permohonan hak atas tanah yang efektif dan efesien dapat terwujud melalui layanan Prima Excellent Service yaitu pelayanan One day Service, Quick Wins Service, Weekend Service, Non stop Service, dan One line Service. Saran dari penelitian ini kepada pemerintah agar selalu melakukan ceck and balance pada kantor kantor pertanahan mengenai pelayanan, kepada kantor pertanahan agar lebih solid dan inovatif demi mewujudkan sistem pelayanan publik yang efektif dan efesian, dan masyarakat agar datang sendiri ke kantor pertanahan untuk melakukan pengurusan tanahnya sendiri, tanpa perantara atau calo.
\end{abstract}

\section{Kata Kunci: Sistem Administrasi pelayanan publik, Permohonan hak atas tanah, Kantor pertanahan.}

\begin{abstract}
The decree of the Head of National Land Affairs Agence of the Republic of Indonesia dated April 22, 2013, No. 6/2013 on Public Information Service in the National Land Affairs of the Republic of Indonesia. The Service Management Operational Procedure Standard and Act No. 25/2009 on Public Service requires that the public service should be fermormed fairly and be citizen-oriented. In practice, the staff at the office still lacked of qualities, unaware of so called Sapta Tertib Pertanahan, and socialization of the service provided by the office. Efficiency and effecttiveness of the service concerning the rights on land affairs have been a perticular interest of the research. Ths research had a purpose to find out the implementation of administration systemof public service Municipal Office of Land Affairs and the concept of efficiency-effectiveness of the proposal for the rights on land at the office. Method used was asocio-legal research based on primary and secondary data. The data obtained were analyzed qualitively. Results of the study revealed that the
\end{abstract}


implementation of administration system of the public service on the rights on land proposal had not been performed properly due to lacking qualities in human resource of the staff. The municipal office actually had applied innovation in servive and technology application in order to be efficient and effective through a service code namely Prima Excellent Service, Non Stop Service, and One Line Service. The research recommended the government to perform a check and balance at the land affairs office dealing with public service, in particular the Tangerang Municipal Office, in order to inspire the similiar agency in other regions. An effective and efficient public service for the proposal of the ringht on land nationwide may help create a good-governance stature fo the public service, which is free of fraud and violation.

Keywords: Public Service Administration System, Rights on Land Proposal, Muinicipal Office of Land Affairs.

\section{Pendahuluan}

Permohonan adalah permintaan kepada yang lebih tinggi kedudukannya ${ }^{1}$, arti hak atas tanah semuanya memberi kewenangan untuk memakai bidang tanah tertentu dalam rangka memenuhi kebutuhan yang hakekatnya pemakaian tanah hanya dibatasi dua tujuan pertama memenuhi tujuan untuk diusahakan misalnya untuk pertanian, perkebunan, perikanan mungkin juga peternakan dan kedua tanah dipakai sebagai tempat untuk membangun sesuatu untuk keperuan macam-macam masing-masing diberi nama Hak Milik, Hak Guna Usaha, Hak Guna Bangunan, dan Hak Pakai ${ }^{2}$.

Administrasi publik dan administrasi negara tidaklah berbeda. ${ }^{3}$ Administrasi negara sebagai konsep tidak lepas dari konsep Aparatur Negara. Dalam praktek pembangunan administrasi negara dalam Garis Besar Haluan Negara (GBHN) dan Rencana pembangunan Lima Tahun (Repelita) disebut pembangunan Aparatur Pemerintah (sampai dengan GBHN 1988) selanjunya disebut Aparatur Negara. GBHN 1999-2004 Pembangunan berbagai dalam dimensi administrasi negara diberi judul Penyelenggaran Negara yang misinya Perwujudan Aparatur Negara berfungsi melayani masyarakat, profesional, berdaya guna, produktif, transparan, bebas dari korupsi, kolusi dan Nepotisme $(\mathrm{KKN})^{4}$. Secara teoritis pemerintah memiliki dua kedudukan sebagai salah satu organ negara dan sebagai administrasi negara ${ }^{5}$.

\footnotetext{
${ }^{1}$ Departemen Pendidikan Nasional, Kamus Besar Bahasa Indonesia Pusat Bahasa, Edisi Keempat, Jakarta, PT.Gramedia Pustaka Utama, Jakarta, 2012 hlm. 925.

2 Boedi Harsono, Hukum Agraria Indonesia Sejarah Pembentukan Undang-Undang Pokok Agraria, Isi dan Pelaksanaannya Jilid 1 Hukum Tanah Nasional, Djembatan, 2008 hlm.285-306.

3 SANKRI (Sistem Administrasi Negara Kesatuan Republik Indonesia), Buku III Lembaga Administrasi Negara RI, Jakarta, 2004, hlm. 8.

4 Ibid, hlm. 9.

${ }^{5}$ Iskatrinah, Pelaksanaan Fungsi Hukum Administrasi Negara dalam Mewujudkan Pemerintahan yang baik, Litbang Pertanahan Indonesia, Litbang Dep.Han, 2014, hlm. 25.
} 
Administrasi Pertanahan bagian dari Administrasi Negara yang bertujuan memberikan pelayanan kepada masyarakat di bidang pertanahan diselenggarakan oleh Badan Pertanahan Nasional (Kementrian ATR/BPN) serta instansi vertikalnya di Daerah Kabupaten/Kota yaitu Kantor Pertanahan. BPN selaku pelaksana utama pelayanan pertanahan kepada masyarakat mempunyai peranan yang sangat besar guna tercapainya tujuan reformasi agraria nasional. Ketentuan Peraturan Kepala BPN tanggal 22 April 2013 Nomor 6 tahun 2013 Tentang Pelayanan Informasi Publik di Lingkungan BPN pada Pasal 4 Pelayanan informasi publik diselenggarakan pada setiap tingkatan di lingkungan BPN, Kantor wilayah Badan Pertanahan Nasional dan Kantor Pertanahan.

BPN satu-satunya institusi yang memiliki kewenangan melaksanakan tugas pemerintah di bidang pertanahan secara nasional, regional dan sektoral. Kewenangan mencakup kegiatan kebijakan, pelayanan publik, baik pelayanan kepada masyarakat, badan hukum swasta, sosial ataupun keagamaan serta institusi pemerintah. Kantor Pertanahan sudah seharusnya melaksanakan prinsip kesederhanaan, kejelasan, kepastian, keamanan, keterbukaan, efisien, ekonoinis, dan keadilan yang merata merupakan prinsip-prinsip ketentuan pendaftaran tanah dalam Peraturan Pemerintah Nomor 24 Tahun 1997 yang harus diakomodasi dalam pelaksanaan sistem administrasi pelayanan publik terhadap permohonan hak atas tanah di Kantor - kantor Pertanahan. Kantor Pertanahan sebagaimana Standar Prosedur Operasional Pengaturan Pelayanan (SPOPP) dan Undang-Undang Nomor 25 Tahun 2009 tentang Pelayanan Publik, fungsi yang dilaksanakan belum optimal akibat keberpihakan dalam memberikan pelayanan terutama dibidang pertanahan.

Secara historis puncak sengketa pertanahan telah terjadi sejak berlakunya undang-undang agraria kolonial 1970 yang dikenal sebagai Agraris Wet, sumber konflik dan sengketa pertanahan adanya ketidakharmonisan, ketidakselarasan atau ketimpangan dalam struktur kepemilikan penguasaan $\operatorname{tanah}^{6}$. Hakekatnya konflik pertanahan yang menjadi sengketa tanah disebabkan kurang tertibnya administrasi, ketimpangan struktur penguasaan dan pemilikan tanah, sistem publikasi pendaftaran tanah yang negatif, meningkatnya kebutuhan tanah, peraturan yang tumpang tindih, masih banyaknya tanah terlantar, kurang cermat notaris dan PPAT dalam menjalankan tugasnya, belum adanya persamaan persepsi dan interpretasi para penegak hukum khususnya dalam pertanahan ${ }^{7}$. Kegiatan dinas luar, peninjauan suatu kegiatan, membantu pekerjaan bagian Subsi ataupun Seksi lain mengakibatkan tugas pokoknya terbengkalai, lemahnya kinerja hlm.12.

${ }^{6}$ Majalah Bumi Bahkti, Mencari akar Sengketa Pertanahan, Edisi 21 Tahun 2000,

${ }^{7}$ Bernhard Limbong, Konflik Pertanahan, Pustaka Margaretha, 2012, Jakarta, hlm. 66. 
pertanahan, terjadinya penyimpangan atau pengingkaran terhadap citra hukum, ketidak akurasian produk sertipikat hak atas tanah, lemahnya sistem administrasi pertanahan, tupang tindih tugas-tugas pelayanan, kinerja pelayanan publik buruk, Manajemen pembagian tugas belum tertata, pembagian tugas antara urusan pelayanan adimnistratif dan membantu tugas pimpinan bercampur aduk. $^{8}$

Peralatan pendukung tidak memadai, kualitas Sumber Daya Manusia (SDM) yang rendah, ketidakmampuan petugas memberikan solusi kepada pemohon karena keputusan harus dari atasan dan berpegang teguh kepada juklak/juknis mengakibatkan kondisi waktu pelayanan relatif lama, koordinasi seharusnya membantu akhirnya menghambat pemberian pelayanan. Persyaratan permohonan hak atas tanah yang tidak lengkap serta pemohon yang tidak kooperatif turut menghambat kinerja pelayanan adimistrasi, andaikan ada koordinasi yang tepat antara pemohon dengan petugas pelayanan, persoalan lagi ketika lokasi tempat tinggal pemohon jauh dari Kantor pertanahan dan kesibukan pemohon membuat penyelesaian permohonan hak atas tanah menjadi lama pada akhirnya menjadi tunggakan pekerjaan. ${ }^{9}$

Hukum tanah (groundrecht) ialah semua norma tertulis maupun tidak tertulis mengenai tanah, yang antara lain mengatur tentang hak dan kewajiban subyek hukum atas tanah, Cara-cara memperoleh tanah, Peralihan hak atas tanah dan Semua perjanjian yang berhubungan dengan tanah. Menurut Mr.B.Ter Haar Bzn membedakan dua macam pengertian mengenai hukum tanah, yaitu : ${ }^{10}$

a. Hukum tanah dalam keadaan diam (groundrecht in rust), mengatur tentang hak-hak atas tanah, baik hak masyarakat hukum atas tanah, maupun mengenai hak perseorangan atas tanah, seperti hak membuka tanah, hak milik, hak memungut hasil, hak wenang pilih/hak wenang beli, hak keuntungan jabatan atas tanah dan sebagainya.

b. Hukum tanah dalam keadaan bergerak (grondrecht in bewoging), mengatur tentang hak untuk memperoleh dan memindahkan hak atas tanah, seperti hak menjual tanah, menghadiahkan tanah, menghibahkan tanah, menyediakan tanah untuk badan hukum adat (wakaf, yayasan) dan sebagainya. Menurut hukum adat yang dapat mempunyai hak atas tanah bukan hanya orang perseorangan, melainkan juga persekutuan hukum. Hak persekutuan hukum atas tanah ini biasanya disebut hak pertuanan atau hak ulayat.

${ }^{8}$ Widhi Handoko, Kebijakan Hukum Pertanahan sebuah refleksi Keadilan hukum Progresif, Thafa Media, Semarang, 2014, hlm 3 s/d 11.

Ibid.

${ }^{10}$ H.A.M Effendy, Pokok-Pokok Hukum Adat, Semarang, Duta Grafika, 1990, hlm. 3. 
Ketentuan dalam pasal 33 ayat (1) UUD 1945 menyebutkan “ bumi air dan ruang angkasa, termasuk kekayaan alam yang terkandung di dalamnya di kuasai oleh negara dan dipergunakan untuk sebesar-besarnya kemakmuran rakyat" bermakna tingkatan tertinggi dikuasai oleh Negara yang di tegaskan kembali dalam Undang-undang Pokok Agraria Nomor 5 Tahun 1960 (UUPA) menyebutkan macamnya hak-hak penguasaan tanah dalam pasal 4 ayat (1) dan (2) yaitu :

(1) “Atas dasar hak menguasai dari Negara sebagai dimaksud dalam pasal 2, ditentukan adanya macam-macam hak atas permukaan bumi, yang disebut tanah yangdapat diberikan kepada dan dipunyai oleh orangorang, baik sendiri maupun bersama-samadengan lain serta dapat badan-badan hukum,

(2) "Hak-hak atas tanah yang dimaksud dalam ayat (1) pasal ini memberikan wewenang untuk mempergunakan tanah yang bersangkutan, emikian pula tubuh bumi dan air serta ruang yang ada di atasnya sekedar diperlukan untuk kepentingan yang langsung berhubungan dengan penggunaan tanah itu dalam batas-batas menurut undang-undang ini dan peraturan -peraturan hukum yang tinggi.

A.P. Parlindungan berpendapat pendaftaran tanah berasal dari kata Cadastre (Bahasa Belanda Kadaster) suatu istilah teknis untuk suatu record (rekaman), menunjukkan kepada luas, nilai, dan kepemilikan (atau lainlain atas hak) terhadap suatu bidang tanah. Kata ini berasal dari bahasa Latin "Capistratum" yang berarti suatu register atau capita atau unit yang diperbuat untuk pajak tanah Romawi (Capotatio Terrens). Dalam arti yang tegas, Cadastre adalah record pada lahan-lahan, nilai dari pada tanah dan pemegang haknya dan untuk kepentingan perpajakan. Dengan demikian, Cadastre merupakan alat yang tepat yang memberikan uraian dan identifikasi dari tersebut dan juga sebagai continuous recording (rekaman yang berkesinambungan) dari hak atas tanah. ${ }^{11}$

Pendaftaran tanah bertujuan memberikan jaminan kepastian hukum dikenal dengan sebutan Rechts Cadaster/Legal Cadaster. jaminan kepastian hukum yang hendak diwujudkan dalam pendaftaran tanah ini, meliputi kepastian status hak yang didaftar, kepastian subjek hak, dan kepastian objek hak. Pendaftaran tanah ini menghasilkan Sertipikat sebagai tanda bukti haknya. Tujuan hukum ${ }^{12}$ meliputi pengertian melindungi secara aktif, artinya

${ }^{1}$ A.P. Parlindungan (Selanjutnya disebut A.P. Parlindungan 1), Pendaftaran Tanah di Indonesia, Mandar Maju, Bandung, 1999, hlm. 18-19.

${ }^{12}$ Soediman Kartohadiprodjo tujuan hukum (termasuk di dalamnya kebijakan hukum pertanahan) yaitu diberikan istilah Pengayoman (Perlindungan), dimana secara singkat padat tujuan hukum adalah mengayomi atau melindungi manusia yaitu bukan hanya melindungi atau mengayomi secara pasif, hanya mencegah tindakan sewenang-wenang dan mencegah 
meliputi upaya untuk menciptakan kondisi dan mendorong manusia untuk selalu memanusiakan diri terus-menerus. sehingga hukum bisa menciptakan kondisi sosial yang manusiawi untuk mengembangkan seluruh kemanusiaannya secara utuh.

Presiden Joko Widodo dalam acara penyerahan sertifikat tanah program strategis tahun 2016 di Lapangan Sepakbola Desa Silawan, Kabupaten Belu, Provinsi Nusa Tenggara Timur (NTT) pada Rabu, 28 Desember 2016 menyampaikan bahwa Kepemilikan sertifikat tanah bagi pemiliknya merupakan hak hukum yang harus dijamin oleh pemerintah, "Sertifikat ini adalah hak hukum bagi pemilik, baik yang tanah adat, yang dulu - letter C atau girik sekarang sudah jadi SHM (Sertifikat Hak Milik)". ${ }^{13}$

\section{Permasalahan}

Berdasarkan latar belakang yang telah diuraikan tersebut, pokok permasalahan dalam tulisan ini adalah pertama bagaimana pelaksanaan sistem administrasi pelayanan publik yang efektif dan efesien di Kantor Pertanahan dalam proses kepastian hukum terhadap hak atas tanah. Kedua bagaimana konsep efesien dan efektif dari sistem administrasi pelayanan pubik hak atas tanah di kantor pertanahan.

\section{Tujuan dan Kegunaan Penelitian}

Berdasarkan permasalahan di atas, tujuan yang hendak dicapai dalam penelitian ini secara teoritis dapat memberikan kontribusi dalam upaya perbaikan birokrasi dan sistem administrasi pelayanan publik di lingkungan Kantor Peratanahan/BPN. Secara Praktis Penulis sendiri dapat memperluas wawasan, mendalami sistem administrasi pelayanan permohonan hak atas tanah yang di terapkan di Kantor Pertanahan, bagi masyarakat diharapkan menjadi hasanah dan informasi terkait pelayanan pada Kantor Pertanahan dengan harapan masyarakat dapat turut berperan aktif dalam percepatan pembangunan. Bagi Pemerintah kiranya dapat menjadikan referensi dalam upaya memperbaiki sistem administrasi pelayanan yang di terapkan di Kantor Pertanahan atau instansi pemerintah lainnya yang saat ini dibutuhkan perubahan pada sistem birokrasi dan sistem pelayanan sebagaimana UUPA Nomor 5 Tahun 1960 tentang Peraturan Dasar Pokok-Pokok Agraria dan Undang-Undang Republik Indonesia Nomor 25 Tahun 2009 tentang Pelayanan Publik.

\section{Metode Penelitian}

pelanggaran hak saja, Baca dalam; Soediman Kartohadiprodjo, Pancasila Sebagai Pandangan Hidup Bangsa Indonesia, Op Cit. hlm xix. Maret 2017

13 http://www.bpn.go.id/Publikasi/Siaran-Pers/pager/662/page/4 diunduh tanggal 11 
Dalam pelaksanaan praktek hukum secara umum ada tiga nilai yang mendasarinya, yakni nilai keadilan, Nilai kemanfaatan hukum, dan Nilai kepastian hukum ditambah kebijakan publik sebagai keputusan yang dibuat oleh pemerintah atau lembaga pemerintahan untuk mengatasi permasalahan tertentu, melakukan kegiatan tertentu atau untuk mencapai tujuan tertentu berkenaan dengan kepentingan dan manfaat orang banyak. Nilai-nilai tersebut ${ }^{14}$ adalah :

1. Nilai Dasar Keadilan

Keadilan hakikatnya bukan terbatas pada definisi atau konsep dalam kaitannya dengan hukum alam ( the natural law), tetapi lebih pada soal praktis menurut Derrida menegakkam hukum tidak sekaligus menciptakan keadilan, pandangan Leon Petrazycki keadilan adalah fenomena yang konkrit yang dapat ditangkap melalui penelitian intuisi kita, Gunawan Setiardi mendefinisikan keadilan dalam arti subjektif suatu kebiasaan baik jiwa yang mendorong manusia dengan kemauan tetap dan terus menerus untuk memberikan kepada setiap orang apa yang menjadi haknya. ${ }^{15}$ Keadilan adalah konkret dengan melihat pernyataan dalam pembukaan Undang-Undang Dasar Negara Republik Indonesia 1945 khususnya alenia ke-4 yang mencantumkan secara eksplisit kata keadilan sosial memiliki makna keadilan bersifat konkrit.

Dasarnya keadilan memiliki ragam makna menyebabkan banyak keragaman dalam definisinya, Jhon Raws mengatakan sebuah masyarat dikatakan baik apabila didasarkan pada dua pronsip yaitu Fairness yang menjamin semua anggota apa pun kepercayaan dan nilai-nilainya, kebebasan semaksimal mungkin dan veil ignorance, yang hanya membenarkan ketiaksamaan sosial dan ekonomi apabila ketidaksamaan itu dilihat dalam jangka panjang justru menguntungkan mereka yang kurang beruntung. ${ }^{16}$ Notonegoro menerangkan hubungan antar manusia dengan tanah baik kolektif maupun individual bersifat dwitunggal dilandasi nilai-nilai sila kedua Pancasila Hubungan antara manusia dengan tanah yang bersifat kolektif dapat dijumpai pada Pasal 1 ayat (1) dan Pasal 2 ayat (1) yang menegaskan bahwa seluruh wilayah Indonesia merupakan kesatuan tanah air dari seluruh rakyat Indonesia yang bersatu sebagai bangsa Indonsia dan bahwa bumi, air dan kekayaan alam itu dalam tingkatan tertinggi dikuasai oleh Negara sebagai organisasi kekuasaan seluruh rakyat. ${ }^{17}$

\footnotetext{
${ }^{14}$ Lapituju dalam http//Lapatuju, blog pot.UM/2013 Keadilan, Kemanfaatan, dan Kepastian, diakses tanggal 11 Maret 2017

${ }^{15}$ Suteki, Rekonstruksi Politik Hukum Hak Atas Air, 2010, Surya Pena Gemilang, Jawa Timur, hlm. 17-20.

${ }_{16}$ Jhon Rawls, A Theory of Justice, Chambridge, Harvard University Press, hlm 11 dalam Suteki, Rekonstruksi Politik Hukum Hak Atas Air, 2010, Surya Pena Gemilang, Jawa Timur, hlm. 20.

${ }_{17}$ Sumardjono Maria S.W, Tanah dalam prespektif hak ekonomi sosial dan budaya, 2007, Kompas, Yogyakarta, hlm. 101.
} 
2. Nilai Dasar Kemanfaatan Hukum.

Teori dasar yang kedua adalah kemanfaatan hukum. prinsip kegunaan/kemanfaatan (utilitas) menjadi doktrin etika, yang dikenal sebagai utilitarianism atau madzhab utilitis. Prinsip utility tersebut dikemukakan oleh Jeremy Benthan dalam karya monumentalnya Introduction to the Principles of Morals and Legislation (1789. ${ }^{18}$ Bentham mendefinisikannya sifat segala benda tersebut cenderung menghasilkan kesenangan, kebaikan, atau kebahagiaan, atau untuk mencegah terjadinya kerusakan, penderitaan, atau kejahatan, serta ketidakbahagiaan pada pihak yang kepentingannya dipertimbangkan. Aliran utilitas menganggap pada prinsipnya tujuan hukum hanyalah untuk menciptakan kemanfaatan atau kebahagiaan masyarakat. Bentham berpendapat, bahwa negara dan hukum semata-mata ada hanya untuk manfaat sejati, yaitu kebahagiaan mayoritas rakyat.

3. Nilai Dasar Kepastian Hukum.

Mahzab Sociological jurisprudence adalah Eugen Ehrlich dan Roscoe Pound mengajarkan bahwa hukum yang baik adalah huku yang sesuai dengan hukum yang hidup di dalam masyarakat (the centre of gravity of legal development lis not legislation, nor in juristic, nor in judicial decision, but in socety) ${ }^{19}$, rumusan tersebut menunjukan kompromi antara hukum tertulis sebagai kebutuhan masyarakat yaitu hukum demi adanya kepastian hukum dengan living law sebagai wujud penghargaan terhadap pentingnya peranan masyarakat dalam pembentukan hukum.

Kepastian hukum atas sertipikat merupakan tujuan utama pendaftaran hak atas tanah, sebagaimana ketentuan pasal 19 UUPA, memperoleh sertifikat, tujuannya bukan sekedar mendapatkan fasilitas, melainkan merupakan hak bagi pemegang Hak Atas Tanah yang dijamin oleh Undang-Undang. ${ }^{20}$ Hak atas tanah yang terdaftar bebas dari segala gugatan orang lain dan demikian pula mengelakkan suatu adegium yang dikenal yaitu nemo dat aquod non habet, pada ketentuan Peraturan Pemerintah 24 tahun 1997 pasal 24 menyebutkan bahwa yang telah menguasai dengan itikad baik suatu bidang tanah selama 20 tahun atau lebih secara berturut-turut dapat dilakukan pendaftaran tanah yang dikuasainyainya tersebut ${ }^{21}$.

4. Kebijakan Publik

Kebijakan publik merupakan suatu ilmu multidisipliner karena melibatkan banyak disiplin ilmu seperti ilmu politik, sosial, ekonomi,dan

\footnotetext{
${ }^{18}$ Lapituju, Op.Cit

${ }^{19}$ MDA Freeman, Llyod's Introduction to jurisprudence, London, Steven\&Sons, Fifth Edition, 1985, hlm.659-700 dalam Sulistyowati\&Sidarta, Metodologi Penelitin Hukum Konstelasi dan Refleksi, 2009, Buku Obor, Jakarta, hlm. 25.

${ }^{20}$ Boedi Harsono, Lok.Cit, hlm. 473.

${ }^{21}$ AP Parlindungan, Pendaftaran Tanah di Indonesia, 2009, Penerbit Bandar Maju, Bandung, hlm.10.
} 
psikologi. Salah satu kebijakan publik dalam sistem negara modern adalah legal politics yang kemudian dipakai sebagai istilah untuk politik hukum. Teori Black Box Kebijakan Publik karya David Easton sangat sesuai relevan menjelaskan berbagai unsur atau lingkungan (environment), yang mempengaruhi pembuatan kebijakan bernama hukum (dalam wujud peraturan perundang-undangan) tersebut, teori ini akan didukung dengan teori-teori kebijakan publik lainnya. ${ }^{22}$ David Easton mendefinisikan kebijakan publik sebagai "pengalokasian nilai-nilai kepada masyarakat", karena setiap kebijakan mengandung seperangkat nilai di dalamnya. ${ }^{23}$ Hukum ada karena keberadaan masyarakat dan sebaliknya. Hukum selalu dalam proses terus bergulir untuk mencapai keadilan.

Metode penelitian menggunakan pendekatan Socio Legal berarti terdapat dua aspek penelitian pertama aspek legal research yakni objek penelitian tetap ada yang berupa hukum dalam arti "norm" peraturan perundang-undangan dan kedua socio research yaitu digunakan metode dan teori ilmu-ilmu sosial tentang hukum untuk membantu peneliti dalam melakukan analisis. Pendekatan ini tetap dalam ranah hukum, hanya perfpektifnya yang berbeda. ${ }^{24}$ Data penelitian dianalisis menggunakan analisis Deskriptif Kualitatif yaitu metode analisa data dengan memaparkan semua data, data primer maupun data sekunder dianalisis berdasarkan teori dan peraturan yang berlaku dan akhirnya dibentuk suatu kesimpulan. ${ }^{25}$ Penarikan kesimpulan menggunakan metode Triangulasi, triangulasi adalah teknik pemeriksaan keabsahan data yang memanfaatkan sesuatu yang lain di luar data itu untuk keperluan pengecekan atau pembanding terhadap data $i t u^{26}$.

\section{Pembahasan}

Administrasi adalah usaha dan kegiatan meliputi penetapan tujuan serta penetapan cara-cara penyelenggaraan pembinaan organisasi atau usaha dan kegiatan yang berkaitan dengan penyelenggaraan kebijakan untuk mencapai tujuan atau kegiatan yang berkaitan dengan penyelenggaraan pemerintah. ${ }^{27}$ Administrasi kata yang berasal dari bahasa latin administrare

\footnotetext{
${ }^{22}$ Suteki, Op.Cit, hlm.15.

23 Ibid.

24 Zamroni, Pengembangan pengantar Teori Sosial, Tiara Yoga, Yogyakarta, 1992
} hlm.80-hlm.81 dalam Widhi Handoko, Kebijakan Hukum Pertanahan sebuah refleksi Keadilan hukum Progresif, Thafa Media, Semarang, 2014, hlm 3 s/d 11. hlm. 34.

${ }^{25}$ Bambang Waluyo, Penelitian Hukum Dalam Praktek, Jakarta, Sinar Grafika, 2002,

${ }^{26} \mathrm{Ibid}, \mathrm{hlm} .330$.

27 Kamus Besar Bahasa Indonesia, Loc.Cit, hlm. 11. 
yang berarti to manage devirasinya antara lain menjadi administrasiti yang berarti besturing atau pemerintahan, dalam Kamus Besar Bahasa Indonesia (KBBI) administrasi diartikan sebagai usaha dan kegiatan yang meliputi penetapan tujuan serta penetapan cara-cara penyelenggaraan pembinaan organisasi, administrasi dapat diartikan juga usaha dan kegiatan yang berkaitan dengan penyelenggaraan kebijaksanaanserta mencapai tujuan, administrasi dapat lagi sebagai kegiatan yang berkaitan dengan penyelenggaraan pemerintah kemudian administrasi juga dapat diartikan suatu kegiatan kantor dan tata usaha. ${ }^{28}$

Fungsi pengaturan maupun fungsi pelayanan menyangkut semua segi kehidupan dan penghidupan masyarakat, berbangsa dan bernegara dan pelakanaannya dipercayakan kepada aparatur pemerintah tertentu yang sevara fungsional bertanggung jawab atas bidang-bidang tertentu dua fungsi tersebut. ${ }^{29}$ Administrasi pertanahan berhubungan dengan berbagai aturanaturan kepemilikan tanah diterapkan dan diopersikan. Administrasi pertanahan baik formal atau informal terdiri dari berbagai pilihan sistem dan proses untuk pengelolaan ${ }^{30}$ yaitu :

1. Hak atas tanah yang mencakup alokasi hak atas tanah, batas batas bidang tanah yang hak tersebut dialokasikan, transper dari satu pihak kepada pihak lain melalui dilokasikan, pemindahan dari satu pihak kepada pihak lain melalui penjualan, sewa, pinjaman, hadiah atau warisan, ajudikasi keraguan dan perselisihan mengenai hak dan batasbatas paket.

2. Regulasi penggunaan tanah yang meliputi perencanaan penggunaann tanah dan pengakan hukum dan ajudikasi konflik penggunaan lahan.

3. Penilaian dan perpajakan tanah terkait pengumpulan pendapat melalui bentuk-bentuk penilaian tanah dan perpajakan, dan ajudikasi sengketa penilaian dan perpajakan tanah.

Informasi atas tanah, orang dan hak-hak atas tanah merupakan dasar administrasi pertanahan yang efektif sejak hak atas tanah tidak ada dalam bentuk fisik dan harus diwakilkan dalam beberapa cara. Pengaturan hukum formal, informasi mengenai hak apakah dipegang oleh individu, keluarga, masyarakat, negara atau organisasi komersial dan lainnya, sering dicatat dalam beberapa bentuk pendaftaran tanah dan sistem kadaster, dalam lingkungan kepemilikan adat, informasinya tidak tertulis dan diadakan dalam masyarakat melalui memori kolektif dan pelibatan saksi.

28 Rochmat Soemitro, Masalah peradilan Adminstrasi dalam Hukum Pajak di Indonesia, Eresco, Jakarta, 1976 hlm.5 dalam Ridwan HR, Hukum Administrasi Negara, Raja Grafindo Persada, Jakarta, 2002, hlm. 25. hlm.128-129.

29 Sondang P.Siagian, Administrasi Pembangunan, Gunung Agung, Jakarta, 1976,

30 Bernhad Limbong, Reforma Agraria, Pustaka Margaretha, Jakarta, 2012, hlm. 54. 
Masyarakat yang memegang hak-hak informal mungkin memiliki bukti informal hak yaitu dokumen diterima oleh masyarakat tetapi tidak oleh administrasi negara formal. Komponen penegakan, perlindungan sangat penting untuk administrasi tanah efektif karena hak atas tanah yang berharga ketika klaim mereka dapat ditegakkan. Komponen seperti itu memungkinkan hak seseorang yang diakui mendapat perlindungan dari tindakan orang lain. Perlindungan ini dapat berasal dari negara atau masyarakat melalui konsensus sosial.

Pengaturan hukum formal, hak dapat diberlakukan melalui sistem pengadilan, pengadilan dan lain-lain. Dalam lingkungan kepemilikan adat, hak dapat diberlakukan melalui para pemimpin adat, hak dapat diberlakukan melalui para pemimpin adat. Dalam kasus kedua, orang dapat dirangsang mengakui hak orang lain melalui mekanisme seperti masyarakat. Orang yang tau hak-hak mereka dan tahu apa yang harus dilakukan jika hak-hak tersebut dilanggar, lebih mampu melindungi hakhak mereka daripada mereka yang kurang mengetahuinya terhadap hak tersebut seperti : ${ }^{31}$

a. Tatacara terhadap atas tanah termasuk mendefinisikan bagaimana hak dapat dipindahkan dari pihak satu kepada pihak lainnya melalui penjualan, sewa, pinjaman, hadiah, warisan, hibah

b. Tatacara pengaturan penggunaan lahan meliputi perumusan cara dimana kontrol penggunaan tanah harus dirancangkan dan dilaksanakan

c. Tatacara penilaian tanah dan perpajakan termasuk merumusan metodologi untuk menilai dan pajak tanah.

Kebijakan pokok pertanahan sekaligus arah pembangunan di bidang pertanahan adalah sukses pemecahan masalah pertanahan, kinerja birokrasi pemerintah dalam rangka peningkatan manajemen pertanahan yang lebih efektif, efisien dan akuntable di lingkungan Badan Pertanahan Nasional Republik Indonesia menetapkan Sapta Tertib Pertanahan pada tanggal 27 Juni 2012 melalui Keputusan Kepala Badan Pertanahan Nasional Republik Indonesia Nomor 277/Kep-7.1/VI/2012 merupakan pedoman dalam pelaksanaan tugas di Semua Pimpinan Unit Kerja dan staf di lingkungan Kantor Pertanahan,Sapta Tertib Pertanahan yaitu :

1) Tertib Administrasi;

2) Tertib Anggaran;

3) Tertib Perlengkapan;

4) Tertib Perkantoran;

5) Tertib Kepegawaian;

6) Tertib Disiplin Kerja; dan

7) Tertib Moral.

${ }^{31}$ Ibid hlm. 56. 
Penyelenggara pelayanan harus memiliki standar dan publikasi sebagai jaminan adanya kepastian bagi penerima layanan, standar pelayanan merupakan ukuran baku dalam penyelenggaraan pelayanan yang wajib ditaati oleh pemberi dan/atau penerima layanan. Dalam penyusunan standar pelayanan harus diketahui output/produk pelayanannya, kemudian segala upaya mencapai output pelayanan tersebut meliputi ${ }^{32}$ :

a) Prosedur Pelayanan berisikan deskripsi seluruh kegiatan pelayanan sampai keluar output pelayanan yang dibakukan, baik bagi pemberi maupun penerima pelayanan, termasuk pengaduan.

b) Janji Pelayanan yang mengakomodasi paramter keprimaan peayanan seperti keramahan, kerapihan, keterbukaan, kompetensi, aksebilitasi, sarana, prasarana.

c) Waktu penyelesaian, yang ditetapkan sejak saat pengajuan permohonan sampai dengan penyelesaian pelayanan termasuk pengaduan.

d) Biaya pelayanan termasuk apabila gratis sesuai dengan katagori pelayanan berdasarkan pertimbangan ekonomi.

Hakekat pelayanan publik adalah pemberian pemenuhan pelayanan kepada masyarakat yang merupakan perwujudan kewajiban pemerintah sebagai abdi masyarakat, pelayanan publik ini terutama diberikan untuk hal-hal yang sifatnya mendasar seperti pendidikan, sosial, keamanan dan ketertiban, lingkungan, perekonomian, kependudukan, ketenagakerjaan dan pertanahan ${ }^{33}$.

Ilmunya administrasi merupakan kegiatan pelayanan dan salah satu fungsi pemerintah dalam pembangunan adalah menyelenggarakan pelayanan publik, Sondang $P$. Siagian mengatakan ${ }^{34}$ teori klasik ilmu administrasi negara mengajarkan bahwa pemerintahan negara pada hakikatnya menyelenggarakan dua jenis fungsi utama, yaitu fungsi pengaturan dan fungsi pelayanan. Fungsi pengaturan biasanya dikaitkan dengan hakikat negara modern sebagai suatu negara hukum (legal state) sedangkan fungsi pelayanan dikaitkan dengan hakikat negara sebagai suatu negara kesejahteraan (welfare state).

Fungsi pengaturan maupun fungsi pelayanan menyangkut semua segi kehidupan dan penghidupan bermasyarakat, berbangsa dan bernegara dan pelaksanaanya dipercayakan kepada aparatur pemerintah tertentu yang secara fungsional bertanggung jawab atas bidang-bidang tertentu kedua fungsi tersebut. Istilah lain yang sejenis dengan pelayanan itu

\footnotetext{
32 SANKRI Ibid, hlm. 391-394.

33 Op.Cit, hlm. 390.

${ }^{34}$ P. Siagian Sondang, Loc.Cit hlm. 128-129.
} 
adalah pengabdian dan pengayoman. Seorang administrator diharapkan mencermin sifat-sifat memberikan pelayanan publik, pengabdian kepada kepentingan umum dan memberikan pengayoman kepada masyarakat lemah dan kecil. Faktor lain yang menyebabkan sulit didapatkan keterangan dan informasi mengenai kinerja pelayanan publik dikarenakan begitu kompleksnya indikator kinerja, yang biasa digunakan untuk mengukur kinerja birokrasi publik. Hal ini disebabkan oleh stakeholders yang sangat banyak dan memiliki kepentingan yang berbeda-beda pada birokrasi publik. Kondisi ini kontras dengan sektor privat yang indikator kinerjanya relatif lebih sederhana.

Kesulitan lainnya dalam mengukur kinerja birokrasi publik adalah dikarenakan tujuan dan misi birokrasi publik seringkali menjadi absurd dan tidak jelas karena sifatnya multidimensional. Konsekuensinya, indikator pengukuran kinerja bagi tiap-tiap stakeholders juga berbedabeda. Namun demikian menurut Dwiyanto ada beberapa indikator yang dapat digunakan mengukur kinerja birokrasi publik yaitu Produktivitas, Kinerja Layanan, Responsivitas, Responsibilitas, Akuntabilitas. ${ }^{35}$ Ekspansi Komputerisasi Kantor Pertanahan dimulai tahun 2002, dimulainya penggunaan basis data spasial, walaupun masih terpisah dengan basis data tekstual serta mulai dilakukan konversi data spasial. Tahun 2006 digitalisasi peta pendaftaran di provinsi DKI Jakarta yang mencakup 70\% bidang tanah terdaftar, dicetuskannya LARASITA hingga tahun 2009 komputerisasi Kantor Pertanahan (KKP) sudah mencakup 274 Kantor Pertanahan. ${ }^{36}$

Tahun 2010 dimulai perombakan atas sistem, aplikasi dan basis data, diadopsinya Land Administration Domain Model (LADM, ISO-19152) sebagai struktur inti basisdata, penggunaan arsitektur aplikasi $N$-Tier, antarmuka pengguna berbasis web, basisdata terpusat di Kantor Pusat BPN RI, perawatan dan pemeliharaan aplikasi dilakukan secara mandiri dan satu basis data untuk data tekstual dan spasial. Sampai tahun 2010 sudah dilakukan implementasi Komputerisasi Kantor Pertanahan (KKP) di 430 (empat ratur tigapuluh) Kantor Pertanahan dengan pembiayaan melalui APBN. Dilaksanakannya KKP adalah transformasi layanan publik pertanahan, tidak ada lagi pelayanan permohonan sertipikat hak atas tanah secara manual, proses permohonan sertipikat hak atas tanah dapat dimonitoring melalui komputer, proses permohonan sertipikat hak atas tanah dapat dilakukan secara tertib dan berurutan (first in first out), terbentuknya data base pertanahan yang selalu up to

${ }^{35}$ Dwiyanto Agus, Dwiyanto Agus, Reformasi Birokrasi Publik di Indonesia, Pusat studi Kependudukan dan Kebijakan, UGM, Yogjakarta, 2002, hlm. 48.

${ }^{36}$ http://bpn.go.id 
date dan dapat digunakan dalam kegiatan pelayanan informasi pertanahan.

Seiring implementasi KKP, dibangun pula database pertanahan melalui kegiatan konversi atau digitalisasi data pertanahan, baik data tekstual (Buku Tanah) maupun data spasial (Surat Ukur dan Peta Pendaftaran Tanah). Sampai dengan medio Agustus 2013 telah tersedia database 32 juta bidang tanah (71\%) dari total 45 juta bidang tanah tardaftar/bersertipikat yang tersebar di 430 Kabupaten/kota dan 33 Propinsi. Selain KKP ada lagi Pelayanan Publik di Kantor Pertanahan yang telah mengalami inovasi yaitu :

(1) Pelayanan Larasita, layanan pertanahan bergerak (mobile land service) yang bersifat pro aktif dengan "hadirnya" petugas BPN RI ke tengah-tengah masyarakat.

(2) One Day Service, layanan satu hari selesai dibidang pertanahan yang dilaksanakan pada Loket Pelayanan Kantor Pertanahan maupun mobil LARASITA. Layanan ini dilaksanakan untuk jenis pelayanan yang dapat diselesaikan dalam jangka waktu 1 hari (1-8 jam) yang dilaksanakan pada hari kerja. layanan pertanahan One Day Service antara lain Pengecekan Sertipikat, Penghapusan Hak Tanggungan (Roya), Pendaftaran Hak Milik Berdasarkan Surat Keputusan, Peningkatan Hak/Perubahan Hak, Peralihan Hak, Surat Keterangan Pendaftaran Tanah (SKPT), Perpanjangan Hak Tanpa Ganti Blanko, Pencatatan Sita, Pencatatan Blokir.

(3) Quick Service, adalah layanan dibidang pertanahan yang dapat diselesaikan lebih cepat dari standar waktu yang telah ditentukan, layanan 1-5 hari kerja dapat diselesaikan dalam waktu 2-8 jam sehingga dapat ditunggu oleh pemohon layanan. Layanan ini meliputi penghapusan Hak Tanggungan (Roya) dengan persyaratan tertentu, perubahan HGB menjadi HM untuk luas tertentu, serta Surat Keterangan Pendaftaran Tanah (SKPT). Disediakan Loket Khusus Quick Service yang memudahkan masyarakat/pemohon layanan, tidak ada penambahan biaya untuk memperoleh layanan cepat atau Quick Service.

(4) Program Layanan Akhir Pekan atau Weekend Service, adalah pelayanan di luar hari kerja yaitu pada akhir pekan atau Hari Sabtu.

Masih ada hambatan dalam proses pencapaian kinerja Kantor Pertanahan yaitu pemahaman persepsi dan koordinasi antara teknis dan keuangan, tingginya beban kerja pada Kantor pertanahan, pelayanan sempat terkendala ketika migrasi KKP dari desktop ke web, pelayanan sempat terkendala ketika proses pelayanan pertanahan dilakukan. Langkah-langkah Kantor Pertanahan dalam menangani kendala dengan 
mengadakan rapat konsultasi internal untuk membahas terkait kegiatan teknis dan sistem pencairan anggaran, melakukan training dan konsultasi secara maksimal untuk mengatasi perubahan aplikasi dari desktop ke Web, melakukan koordinasi instansi pusat atau Kantor pemerintah lainnya, terkait dokumen-dokumen yang perlu dipindahkan seperti buku tanah, hingga sarana dan prasarana untuk melakukan Trainning Service Excellent untuk meningkatkan mutu front office, melakukan konsultasi ke BPN Provinsi maupun ke BPN Pusat untuk memperoleh saran/solusi. Antisipasi kendala dilakukan dengan langkah-langkah berikut :

(a) Tetap menyelenggarakan rapat kerja internal, hal ini berfungsi untuk menyamakan persepsi antara teknis dan keuangan. Adanya peraturanperaturan baru juga perlu diinformasikan pada forum ini. Selain membahas rencana kegiatan, rapat berguna untuk menyampaikan evaluasi kinerja sehingga progress-nya dapat terkontrol dengan baik.

(b) Tetap melakukan konsultasi ke BPN Provinsi dan Ke BPN Pusat ketika menghadapi permasalahan yang sulit diatasi

(c) Untuk meningkatkan kualitas pelayanan, perlu diselenggarakan training service excellent pada tingkat manajerial.

(d) Meningkatkan kinerja pegawai dengan character building, yang diharapkan dapat mempererat rasa solidaritas. 


\section{Penutup}

Kesimpulan :

Pertama, Berdasarkan hasil penelitian dan pembahasan penulis menarik kesimpulan Pelaksanaan Sistem administrasi pelayanan publik di kantor pertananahan mengalami perubahan, meski belum maksimal diharapkan kemampuan Sumber Daya Manusia pegawai dapat merata mengenai pengetahuan tentang permohonan hak atas tanah, sehingga setiap permohonan berjalan sampai selesai dengan seefektif dan seefesien mungkin.

Kedua, Sistem loket sudah mulai diterapkan dan sistem komputerisasi, namun sistem dan fasilitas Kantor Pertanahan masih belum banyak diketahui masyarakat sehingga masih saja banyak proses dilakukan pada hari-hari kerja reguler, pelayanan hari weekend belum banyak dimanfaatkan masyarakat, pelayanan publik pertanahan telah di kembangkan melalui inovasi layanan Prima Excellent Service yaitu pelayanan One day Service, Quick Wins Service, Weekend Service, Non stop Service, dan One line Service, sangat disayangkan bila masyarakat belum memamfaatkan pelayanan tersebut.

\section{Saran:}

Pertama, Saran kepada Pemerintah pembuat undang-undang (legislatif) agar dapat membuat peraturan perundang-undangan yang mengakomodasikan terperinci mengenai pelaksanaan sistem pelayanan permohonan hak atas tanah, Pemerintah agar melakukan ceck and balance pada kantor pertanahan mengenai pelayanan, sehingga pelayanan selalu terkontrol, Strategi sistem administrasi melalui Oneline sistem untuk pelayanan pendaftaran hak atas tanah di Kantor Pertanahan.

Kedua, Kepada pelayan masyarakat kiranya pelayanan semakin efektif dan efesien mengadakan pemberitahuan sebagai sarana iklan lebih sering lagi kepada masyarakat sehingga masyarakat mengetahui dan merasa dekat akan sistem pelayanan publik yang, diharapkan kepada masyarakat melakukan kepengurusan tanahnya oleh diri sendiri, tanpa perantara atau calo, sehingga tidak dimanfaatkan oleh pihak yang berkepentingan. 


\section{Daftar Pustaka}

A.P. Parlindungan (Selanjutnya disebut A.P. Parlindungan 1), Pendaftaran Tanah di Indonesia, Mandar Maju, Bandung, 1999.

Bambang Waluyo, Penelitian Hukum Dalam Praktek, Jakarta, Sinar Grafika, 2002.

Bernhard Limbong, Konflik Pertanahan, Pustaka Margaretha, Jakarta, 2012.

, Reforma Agraria, Pustaka Margaretha, Jakarta, 2012.

Boedi Harsono, Hukum Agraria Indonesia Sejarah Pembentukan UndangUndang Pokok Agraria, Isi dan Pelaksanaannya Jilid 1 Hukum Tanah Nasional, Djembatan, 2008.

Dwiyanto Agus, Dwiyanto Agus, Reformasi Birokrasi Publik di Indonesia, Pusat studi Kependudukan dan Kebijakan, UGM, Yogyakarta, 2002.

Departemen Pendidikan Nasional, Kamus Besar Bahasa Indonesia Pusat Bahasa, Edisi Keempat, Jakarta, PT.Gramedia Pustaka Utama, Jakarta, 2012.

Iskatrinah, Pelaksanaan Fungsi Hukum Administrasi Negara dalam Mewujudkan Pemerintahan yang baik, Litbang Pertanahan Indonesia, Litbang Dep.Han, 2014.

H.A.M Effendy, Pokok-Pokok Hukum Adat, Semarang, Duta Grafika, 1990.

Jhon Rawls, A Theory of Justice, Chambridge, Harvard University Press, hlm 11 dalam Suteki, Rekonstruksi Politik Hukum Hak Atas Air,Surya Pena Gemilang, Jawa Timur, 2010.

MDA Freeman, Llyod's Introduction to jurisprudence, London, Steven\&Sons, Fifth Edition, 1985, dalam Sulistyowati\&Sidarta, Metodologi Penelitin Hukum Konstelasi dan Refleksi, Buku Obor, Jakarta, 2009.

Majalah Bumi Bahkti, Mencari akar Sengketa Pertanahan, Edisi 21 Tahun 2000

Sondang P.Siagian, Administrasi Pembangunan, Gunung Agung, Jakarta, 1976

Rochmat Soemitro, Masalah peradilan Adminstrasi dalam Hukum Pajak di Indonesia, Eresco, Jakarta, 1976.

Ridwan HR, Hukum Administrasi Negara, Raja Grafindo Persada, Jakarta, 2002. 
SANKRI (Sistem Administrasi Negara Kesatuan Republik Indonesia), Buku III Lembaga Administrasi Negara RI, Jakarta, 2004.

SulistyowatiqSidarta, Metodologi Penelitin Hukum Konstelasi dan Refleksi, Buku Obor, Jakarta, 2009.

Sumardjono Maria S.W, Tanah dalam prespektif hak ekonomi sosial dan budaya, Kompas, Yogyakarta, 2007.

Suteki, Rekonstruksi Politik Hukum Hak Atas Ai, Surya Pena Gemilang, Jawa Timur, 2010.

Widhi Handoko, Kebijakan Hukum Pertanahan sebuah refleksi Keadilan hukum Progresif, Thafa Media, Semarang, 2014.

Zamroni, Pengembangan pengantar Teori Sosial, Tiara Yoga, Yogyakarta, 1992.

Peraturan Perundang-undangan :

Undang-Undang Dasar Negara Republik Indonesia Tahun 1945;

Undang-Undang Republik Indonesia Nomor 5 Tahun 1960 tentang Peraturan Dasar Pokok-Pokok Agraria;

Undang-Undang Republik Indonesia Nomor 25 Tahun 2009 tentang Pelayanan Publik

Peraturan Pemerintah Nomor 24 Tahun 1997 tentang Pendaftaran Tanah;

Peraturan Menteri Negara Agraria/Kepala Badan Pertanahan Nasional Nomor

3 Tahun 1997 tentang Ketentuan Pelaksanaan Peraturan Pemerintah Nomor 24 Tahun 1997 Tentang Pendaftaran Tanah;

Peraturan Pemerintah Republik Indonesia Nomor 13 Tahun 2010 Tentang Jenis dan Tarif Atas Jenis Penerimaan Negara Bukan Pajak Yang berlaku pada Badan Pertanahan Nasional

Keputusan Presiden Republik Indonesia Nomor 34 Tahun 2003 tentang Kebijakan Nasional di Bidang Pertanahan;

Peraturan Presiden Republik Indonesia Nomor 63 Tahun 2013 tentang Badan Pertanahan Nasional;

Peraturan Kepala Badan Nomor 1 tahun 2010 tentang SPOPP (Standar Prosedure Operasional Peraturan Pelayanan) 